\title{
Asthma risk factors
}

Elina Toskala, MD, $\mathrm{PhD}^{1}$ and David W. Kennedy, MD²

Background: Bronchial asthma is one of the most common chronic diseases in childhood, with a current prevalence of $6 \%$ to $9 \%$, but a prevalence that is increasing at an alarming rate. Asthma is a complex genetic disorder with strong environmental influence. It imposes a growing burden on our society in terms of morbidity, quality of life, and healthcare costs. Despite large-scale efforts, only a few asthma genes have been confirmed, suggesting that the genetic underpinning of asthma is highly complex.

Methods: A review of the literature was performed regarding atopic and nonatopic asthma risk factors, including environmental risk factors and genetic studies in adults and children.

Results: Several environmental risk factors have been identified to increase the risk of developing asthma such as exposure to air pollution and tobaccos smoke as well as occupational risk factors. In addition atopy, stress, and obesity all can increases the risk for asthma in genetically susceptible persons.
Conclusion: Asthma represents a dysfunctional interaction with our genes and the environment to which they are exposed, especially in fetal and early infant life. The increasing prevalence of asthma in all age groups indicate that our living environment and immunity are in imbalance with each other reacting with airway inflammation to the environmental exposures and often non-harmful proteins, such as allergens causing the current "asthma and allergy epidemic." Because of the close relationship between asthma and chronic rhinosinusitis, it is important that otolaryngologists have a good understanding of asthma, the etiologic factors associated with disease, and its evaluation and management. (C) 2015 ARS-AAOA, LLC.

\section{Key Words:}

air pollution; allergens; asthma; atopy; environmental risk factors; epigenetics; genetic risk factors; hygiene hypothesis; microbes; risk factors

How to Cite this Article:

Toskala E, Kennedy D. Asthma risk factors. Int Forum Allergy Rhinol. 2015;5:S11-S16.
A sthma is a chronic respiratory disorder with a heterogeneous and multifactorial background manifested as episodes of wheezing, coughing, and shortness of breath, with about $75 \%$ of the patients having coexisting atopy. It has been estimated that in total, more than 25 million children and adults in the United States have asthma and that globally over 300 million persons suffer from asthma. ${ }^{1-3}$ Epidemiological studies have shown that asthma is more prevalent in women than in men and more prevalent among children, especially boys, who have higher prevalence of asthma compared to girls. ${ }^{4}$ It is the most common chronic

${ }^{1}$ Department of Otorhinolaryngology-Head and Neck Surgery, Temple University, Philadelphia, PA; ${ }^{2}$ Department of

Otorhinolaryngology-Head and Neck Surgery, Perelman School of

Medicine, University of Pennsylvania, Philadelphia, PA

Correspondence to: Elina Toskala, MD, PhD, Department of

Otorhinolaryngology-Head and Neck Surgery, Temple University, 3440 N.

Broad Str., Kresge West, 3rd Floor, Philadelphia, PA 19140;

e-mail: elina.toskala@temple.edu

Potential conflict of interest: None provided.

Received: 22 April 2015; Accepted: 26 April 2015

DOI: 10.1002/alr.21557

View this article online at wileyonlinelibrary.com. disease of childhood. The prevalence has been increasing at an alarming rate and has more than doubled in last the decade. Over 9 million children in the United States have been diagnosed with asthma, of whom $75 \%$ have active disease. $^{1}$

Asthma also has different prevalence among ethnic groups. It is more prevalent among African Americans of all ages $(11 \%)$ and among African American children (17\%) than in any other ethnic group. ${ }^{4}$ Furthermore, a disproportionately large number of children with asthma are from low-income families. Asthma is a major cause of work and school absences, and it is the third leading cause of hospitalization of children under the age of 15 years. $^{1}$

Although asthma is usually recognized through the acute episodes of asthma attacks, including wheezing and sometimes irreversible declines in lung function, it has become appreciated that asthma has an important immune system component as well. Roles for many immune cells and mediators have been described. There is a clear connection between asthma and atopy, although this connection is not absolute. Atopic individuals are more prone to developing asthma, and much of the prevalence of asthma can be linked 
to specific allergies. ${ }^{5}$ However, not all atopic individuals develop asthma, and not all asthmatics have detectably elevated allergic responses. Dysregulated immunity appears to be important in the development of asthma, with elevated serum immunoglobulin E (IgE) levels, excess release of allergic mediators from mast cells, infiltration of eosinophils into the lungs and inflammation in the airways and with skewed T helper 1 (Th1) and Th2 responses. Reduction of chronic inflammation in the lungs is part of a strategy for long-term control of asthma, through the use of antiinflammatory agents such as inhaled glucocorticoids.

Both family-based and twin studies indicate that asthma is a complex genetic disorder. ${ }^{6}$ Multiple genetic and environmental factors are also known to modulate the clinical expression of the disease and its associated phenotypes-bronchial hyperresponsiveness, atopy, and elevated IgE. ${ }^{7}$ Asthma is generally believed to result from gene-environment interactions. There are several wellknown risk-factors for developing asthma and these are discussed in this article.

\section{Environmental risk factors Tobacco}

Active smoking has been shown to be risk factor for developing asthma; women who smoke are at particular risk. Interestingly, the prevalence of smokers among asthmatics is almost the same as it is in the general population. It has been shown that it is more difficult to maintain asthma control in smokers with asthma than in nonsmokers with asthma. Altered airway inflammation and corticosteroid insensitivity are thought to be the mechanisms behind the adverse effects of smoking in asthma patients. ${ }^{8-11}$

A number of studies have shown a clear association between smoking and an increased risk of developing asthma. ${ }^{12-16}$ This correlation was studied in a large 10year follow-up study of patients with allergic rhinitis. ${ }^{17}$ This study showed that active smoking was strongly predictive of the development of new onset asthma in allergic adults. In addition, this study also showed that there was a dose-response relationship between the effect of smoking exposure and the risk of new onset asthma. Several epidemiological studies have also shown strong a correlation between parental smoking and the development of asthma in children. ${ }^{18-21}$ A recent systematic review and meta-analysis of 76 studies examining the effect of exposure to prenatal or postnatal passive smoke reported a $21 \%$ to $85 \%$ increased risk of incident asthma in children. ${ }^{20}$ Similarly, secondhand tobacco smoke (SHS) exposure is also associated with the development of asthma in adolescents and adults. ${ }^{19}$ Interestingly, childhood exposure to passive smoke has also been shown to be associated with an increased risk of developing asthma as an adult, with an odds ratio (OR) of $1.9(95 \%$ confidence interval [CI], 1.6 to 3.2). ${ }^{22}$ Thus, it seems that the increased risk after being exposed to SHS in childhood can be carried into the adulthood.
SHS exposure is particularly relevant in urban childhood asthma because more than one-half of inner-city U.S. children with asthma live with a smoker at home. ${ }^{23}$ Although some studies have reported no effect of SHS exposure on asthma symptoms or asthma-related healthcare use, ${ }^{24}$ others have found a clear association between SHS exposure and asthma morbidity in children. ${ }^{25,26} \mathrm{~A}$ recent public smoking ban in the United Kingdom was associated with a marked reduction in childhood asthma hospitalizations, suggesting a causal link between SHS exposure and childhood asthma morbidity. ${ }^{27}$

\section{Pollution}

Despite attempts and some successes to improve air quality over the decades, current U.S. national trends suggest that exposure to outdoor and indoor air pollution remains a significant risk factor for both the development of asthma and the triggering of asthma symptoms. ${ }^{28}$

A substantial disparity in asthma prevalence and morbidity among urban children compared to non-urban children has been recognized for more than 2 decades. ${ }^{29}$ Because of the nature of urban neighborhoods, pest allergens, such as cockroach and mouse, are present in high concentrations in U.S. urban housing and both of these allergens are linked to asthma morbidity in sensitized children. ${ }^{30}$ In addition, there is a growing body of evidence showing that concentrations of many pollutants are higher indoors than outdoors in both U.S. and European urban communities and that exposures to indoor pollutants such as particulate matter (PM) and nitrogen dioxide $\left(\mathrm{NO}_{2}\right)$ are independently associated with symptoms in children with asthma. ${ }^{29}$ It has been shown that environmental interventions can reduce relevant indoor allergen and pollutant exposures and they are associated with clear improvements in asthma. ${ }^{31,32}$ Other modifiable risk factors in urban childhood asthma include dietary and nutritional factors, being overweight, and insufficient vitamin $\mathrm{D}$ and folate, all of which have been shown to increase both the risk of asthma and asthma morbidity in children. ${ }^{33-35}$

The best-studied indoor pollutants include airborne PM, $\mathrm{NO}_{2}$, and SHS. Airborne PM is typically measured in different-sized fractions, so that fine PM is considered PM with an aerodynamic diameter of $2.5 \mu \mathrm{m}$ or less (PM2.5) and coarse PM is considered PM with an aerodynamic diameter of greater than $2.5 \mu \mathrm{m}$ and up to $10 \mu \mathrm{m}$ (PM2.510). Both fine and coarse PM comprise PM10. SHS exposure is composed of many substances, which are both particulate and gaseous in nature. SHS contributes predominantly to the fine particle (PM2.5) fraction of airborne PM, and the most commonly measured gaseous component of SHS is airborne nicotine. ${ }^{30}$

It has been shown that the indoor PM concentrations in urban homes is as much as 2 times higher than the concentrations in nonurban homes. ${ }^{36-40}$ The most common indoor sources for PM2.5 and PM10 are smoking, sweeping, and stove use. Both indoor PM2.5 and PM2.5-10 exposures are 
associated with more asthma symptoms and rescue medication use in urban children with asthma. ${ }^{37}$ Additionally, $\mathrm{NO}_{2}$ is the byproduct of combustion reactions, and homes with gas-powered appliances have higher levels of $\mathrm{NO}_{2}$ than homes without gas-powered appliances; also, indoor $\mathrm{NO}_{2}$ levels are higher than outdoor $\mathrm{NO}_{2}$ levels in urban homes. In many U.S. cities, gas stoves and heat are prevalent, and some families will use their gas stoves and ovens for heat. In contrast to $\mathrm{PM}$, outdoor $\mathrm{NO}_{2}$ has little to no influence on indoor $\mathrm{NO}_{2}$ concentrations. ${ }^{30}$

Additional aspect to the problem is that susceptibility to the respiratory effects of exposure to air pollution has been shown to be elevated within overweight patients. ${ }^{41}$ It has been reported that overweight or obese children had more asthma symptoms, but not worse lung function or airway inflammation, after higher exposure to fine particulate matter and $\mathrm{NO}_{2}$ than normal-weight participants across a range of asthma symptoms. ${ }^{42}$

\section{Obesity}

In addition to increasing the risks of the respiratory effects of air pollution, obesity alone has a significant impact on asthma risk, phenotype, and prognosis. Epidemiological studies have clearly demonstrated that asthma is more likely to occur in obese patients, and health status is impaired in obese individuals with asthma, with such asthmatics experiencing more symptoms, worse quality of life, increased healthcare use, and increased asthma severity. ${ }^{43,44}$

It has been suggested that immunological mechanisms and increased airway inflammation relevant to both disorders may link asthma and obesity. In addition to increasing the risk of developing asthma, these pathways may also converge to enhance airway inflammation, and skew asthma toward a more difficult-to control phenotype, ${ }^{45,46}$ as well as altering response to therapy, ${ }^{47,48}$ particularly glucocorticoid (GC) response. However, it has also been shown that obesity can cause dyspnea and asthma symptoms, mechanically reducing lung function without any inflammatory effects. The relationship between obesity and asthma is an important one for additional study.

\section{Occupational risk factors}

Work environment is an important potential risk factor for asthmatic patients both as a risk factor in terms of its development, and in terms of disease exacerbation. Occupational asthma $(\mathrm{OA})$ is a form of asthma that is often underdiagnosed and underreported, and when unrecognized can lead to progression of disease and increased morbidity. Traditionally, sensitizers to occupational asthma have been divided into high-molecular weight compounds (HMW) and low-molecular weight compounds (LMW). ${ }^{49}$ The most relevant causes of HMW agents include flour dust, enzymes (plant and animal derived), gums, foods, tobacco, rubberderived proteins, animal-derived and insect-derived allergens, and fish/seafood-derived allergens. The most relevant LMW agents include Western red cedar, polyisocyanates and their polymers, acid anhydrides, metals, and a spec- trum of chemical substances..$^{50,51}$ The diagnosis of OA has a significant impact on the future employment, health, and the socioeconomics of the worker, but this should be considered in every asthma patients with poor asthma control. It is critical to keep in mind that a careful history of workrelated exposures is included in evaluation of a patient with chronic cough, asthma, and allergic rhinitis. ${ }^{52}$

\section{Microbes}

Viral and bacterial infections are important factors in asthma pathogenesis, and patients with asthma may be more susceptible to viral and bacterial infections as a result of impaired mucosal and systemic immune defense and atopy. Bacterial colonization of the airway and gut mucosal surfaces seem to play an important part in the defense mechanism, and both host factors and the result of infections contribute to the development and progression of asthma. ${ }^{53}$

Viral infections are the most common cause for upper and lower respiratory tract infections (URTI and LRTI). The most commonly identified viruses causing respiratory tract infections in children are human rhinoviruses (HRVs), respiratory syncytial virus (RSV), influenza and parainfluenza viruses, coronavirus, adenovirus, human metapneumovirus, and bocavirus. ${ }^{54-56}$ Several studies have shown that there is an association between early viral LRTIs and the development of childhood wheeze and asthma. ${ }^{54,57,58}$ The mechanism of this association is not clear, but potential mechanisms could be that viruses might predispose to the onset of wheeze and asthma, that viral infections merely unmask host factors underlying disease susceptibility, or that viruses might trigger wheeze and asthma and thereby aggravate airway inflammation. ${ }^{57}$ The role of the bacterial microbiome in shaping immune responses to viral infections is currently unknown.

In a longitudinal birth cohorts study, ${ }^{59}$ viral LRTI during the first 3 years of life was shown to be an independent determinant of wheeze at age 6 years. This risk decreased until age 11 to 13 years and was accompanied by a reduction in forced expiratory volume and increased responsiveness to salbutamol, implying a lasting change in the regulation of airway smooth muscle tone. Another birth cohort study reported that about $13 \%$ of childhood asthma cases were attributable to infant LRTIs during the RSV season. ${ }^{60}$

In a recent review by Fuchs and von Mutius, ${ }^{53}$ the authors propose a theory for the role of viruses and bacteria in the development of childhood asthma. They identify 4 primary components that could be attributed to the development of asthma: (1) altered airway function and mechanics; (2) impaired mucosal immune responses; (3) impaired systemic immune responses; and (4) atopic sensitization. These components could be formed prenatally depending on the genetic background of the mother and offspring, as well as by maternal environmental exposures during pregnancy, such as tobacco smoke, antibiotic use, infections, and microbial environments. 


\section{Hygiene hypothesis}

Childhood infections and exposure to certain microbial antigens on the other hand seem to present a strong negative correlation with allergies, and therefore the increase of the allergic burden in the Western world has been frequently related to a decline of childhood infections, giving birth to the "hygiene hypothesis." The hygiene hypothesis is based on large epidemiological data demonstrating an increased incidence of asthma and allergic disease in the industrialized world during the last several decades. During this same time period, the increased use of antibiotics, improved hygiene, and urbanization presumably decreased childhood exposure to previously common infections, diverse environmental microorganisms, and their products. ${ }^{61,62}$ These events, suggest an inverse relationship between microbiologic diversity and atopic disease, also known as the hygiene hypothesis. An early and prolonged imbalanced expression of the TH2 allergic phenotype can persist in those without an appropriate TH1-directed response to infection in early life. This is supported by mouse models in which pathogen exposure before allergic sensitization favors decreased airway inflammation, airway hyperresponsiveness, and TH2-related cytokines with allergen re-exposure. ${ }^{63}$ Recognition of the human microbiome and its systemic immune-modulatory effects further contribute to the hygiene hypothesis although the hypothesis remains somewhat controversial and more studies are needed to evaluate the role of "hygiene" in the development and prevention of allergic diseases.

One of the important findings from the studies of the hygiene hypothesis is that repeated stimulation of the immune system by pathogens has important role in the development of allergic diseases. Besides a potentially protective role of early exposure to bacterial antigens, it is important to emphasize that exposure to both Gram-negative (LPS) and Gram-positive (superantigen) bacterial antigens in already sensitized individuals may promote inflammatory responses, leading to increased severity of allergic disease and asthma. Several factors, such as the route and the period of exposure, the dose, and the genetic background of each patient determine the outcome of the immune response to the pathogens. ${ }^{64}$

\section{Stress}

Current evidence suggests a causal association between chronic psychosocial stress and asthma or asthma morbidity. Recent findings suggest potential mechanisms underlying this association, including changes in the methylation and expression of genes that regulate behavioral, autonomic, neuroendocrine, and immunologic responses to stress. There is also evidence suggesting the existence of susceptibility genes that predispose chronically stressed youth to both posttraumatic stress disorder (PTSD) and asthma. ${ }^{65}$

In a study of more than 1200 (predominantly African American) adults exposed to traumatic events, the authors found implications of the pituitary adenylate cyclaseactivating peptide (PACAP)-PAC1 receptor pathway on the pathogenesis of PTSD. ${ }^{66}$ In this study both PACAP38 (PACAP peptide containing 38 residues) blood levels and the $\mathrm{C}$ allele of a functional single-nucleotide polymorphism (SNP) (rs2267735) in an estrogen-receptor element of the gene for the PAC1 receptor (ADCYAP1R1) were significantly associated with PTSD or more PTSD symptoms in female but not in male subjects.

\section{Genetics of asthma}

As discussed in the previous section, asthma is a complex genetic disorder. Several genetic and environmental factors are also known to modulate the clinical expression of the disease and its associated phenotypes. In addition to environmental exposures, genetic factors have an important effect on the inception, severity, and treatment of asthma.

Twin studies have shown that there is a genetic element to asthma susceptibility, with heritability of the condition estimated at between 0.36 and $0.77 . .^{67-70}$ The first study to link a genetic locus (chromosome 11q13) to asthma was published in $1989 .{ }^{71}$ Since then more than 600 candidate genes have been described in more than 1000 publications in relation to asthma or an associated phenotype, such as elevated IgE levels, bronchial hyperresponsiveness, or eosinophilia.

Despite the large number of candidate genes identified for asthma, surprisingly few of these candidate gene discoveries have been rigorously replicated, and many have been examined and failed replication in subsequent studies. ${ }^{72-74}$ Genes that have been extensively replicated include the beta2 adrenergic receptor gene, ${ }^{75-77}$ as well as genes involving cytokines, receptors, signaling proteins, and transcription factors involved in Th1 and Th2 cell differentiation, such as IL4, IL4RA, IFNG, IFNGR1, STAT6, GATA3, and $T B X 21,{ }^{78-85}$ as well as genes involved in the cellular responses that characterize atopic disease, such as IL13 and its receptor and the FCER $1 B$ gene. ${ }^{86-90}$

Over the past decade, genomewide association studies (GWASs) have been used extensively to investigate the genetic bases of common complex diseases, including asthma. ${ }^{91,92}$ Before GWAS, many candidate gene studies were performed for asthma susceptibility ${ }^{93,94}$; however, most of the positive associations were not replicated in GWASs, because of differences in either phenotype definition or the populations studied (either in terms of ancestry or environmental exposures), or because of false positives. Approximately $30 \mathrm{GWASs}$ have been reported in different populations in the investigation of chromosomal regions that are linked to asthma and atopy, or related phenotypes such as elevated IgE levels, wheezing, and bronchial hyperresponsiveness. The function of the genes are still incompletely known but the has been shown that polymorphisms of different genes affect the origins of asthma, its severity, and its responses to treatment.

\section{Epigenetics}

The epigenetic data regarding asthma and allergic disease has expanded in the last decade. Previously thought of only in terms of cell differentiation, it is now evident that 
epigenetic events regulate many processes. With T cell activation, commitment toward an allergic phenotype is tightly regulated by DNA methylation and histone modifications at the Th2 locus control region. When normal epigenetic control is disturbed, either experimentally or by environmental exposures, Th1/Th2 balance can be affected..$^{95}$

Chemical modification of DNA and histone proteins that can be passed down to offspring could have a crucial role in translating environmental interactions into changes in expression of specific disease-related genes. Epigenomewide association studies are a promising approach through which this interaction can be systematically explored. ${ }^{96}$ However, investigators have to be cautious when the direction of causality is unknown, because epigenetic changes could be either a cause or a consequence of disease. ${ }^{97} \mathrm{In}$ vestigation of epigenetic processes (such as $\mathrm{CpG}$ methylation and histone modification) and genomewide interaction studies are providing new insights into how environmental and genetic factors interact.

Development of allergy and asthma is determined by interplay between environmental and inherited factors, the later accounting for over one-half of the risk. ${ }^{98}$ Interestingly, this is in high contrast with the low fraction of variance in asthma prevalence $(4 \%)$ that can be accounted for by genetic loci in a large-scale GWAS. ${ }^{99,100}$ As with other complex diseases, GWASs have identified common genetic variants that confer susceptibility to asthma but do not account for a large proportion of its heri- tability. This "missing heritability" of asthma might be explained by unaccounted phenotypic heterogeneity, ${ }^{101}$ structural variation (eg, copy number variants), ${ }^{102}$ rare genetic variants with strong effects, ${ }^{103}$ gene-gene interactions, ${ }^{104}$ gene-environment interactions, ${ }^{105,106}$ or epigenetic mechanisms, such as DNA methylation ${ }^{107}$ or microRNAs.

\section{Conclusion}

Asthma is a common disorder with a dramatically increased incidence in the past decades. There are several theories as to why this increase is happening, but the reasons for this epidemic in Westernized nations are not fully known. It seems however, that there is an association with a Th-1-Th2 imbalance which is affected by decreased and altered microbial exposure, pollution, epithelial microbiome changes, increased obesity, and nutritional factors. Although the genetic aspects of the disease have been widely investigated and many candidate genes identified, epigenetic and environmental factors appear to play a major part in phenotype expression, and additional work is required to further explore the epigenetics of this disease. Because of the close relationship between asthma and chronic rhinosinusitis, especially eosinophilic nasal polyposis, it is important that otolaryngologists and especially rhinologists have a good understanding of asthma, the etiologic factors associated with disease, and its evaluation and management. \&

\section{References}

1. American Lung Association. Asthma \& Children Fact Sheet. September 2014. http://www.lung. org/lung-disease/asthma/resources/facts-and-figures/ asthma-children-fact-sheet.html. Accessed May 14, 2015.

2. American Lung Association. Asthma in Adults Fact Sheet. October 2012. http://www.lung.org/lungdisease/asthma/resources/facts-and-figures/asthmain-adults.html. Accessed May 14, 2015.

3. World Health Organization. Global surveillance, prevention and control of chronic respiratory diseases: a comprehensive approach. 2007. tory diseases: a comprehensive approach. 2007. 41563468_eng.pdf. Accessed May 14, 2015.

4. Centers for Disease Control and Prevention (CDC). CDC Vital Signs. Asthma in the US. Growing every year. May 2011. http://www.cdc. gov/VitalSigns/Asthma. Accessed May 14, 2015.

5. American Lung Association. Lung Disease Data: 2008. http://www.lung.org/assets/ documents/publications/lung-diseasedata/LDD 2008.pdf. Accessed May 14, 2015.

6. Allen M, Heinzmann A, Noguchi E, et al. Positional cloning of a novel gene influencing asthma from chromosome 2q14. Nat Genet. 2003;35:258-263.

7. Anderson SD. Indirect challenge tests: airway hyperresponsiveness in asthma: its measurement and clinical significance. Chest. 2010;138(2 Suppl):25S-30S.

8. Rabe KF, Adachi M, Lai CKW, et al. Worldwid severity and control of asthma in children and adults: the global asthma insights and reality surveys. $J \mathrm{Al}$ lergy Clin Immunol. 2004;114:40-47.

9. Vozoris NT, Stanbrook MB. Smoking prevalence, behaviours, and cessation among individuals with COPD or asthma. Respir Med. 2011;105:477-484.

10. Cerveri I, Cazzoletti L, Corsico A, et al. The impact of cigarette smoking on asthma: a population-based international cohort study. Int Arch Allergy Immunol. 2012;158:175-183.

11. To T, Stanojevic S, Moores G, et al. Global asthma prevalence in adults: findings from the cross- sectional world health survey. BMC Public Health. 2012;12:204

12. Flodin U, Jonsson P, Ziegler J, et al. An epidemiologic study of bronchial asthma and smoking. Epidemiol ogy. 1995;6:503-505.

13. Toren K, Hermansson BA. Incidence rate of adult onset asthma in relation to age, sex, atopy, and smoking: a Swedish population-based study of 15813 adults. Int J Tuberc Lung Dis. 1999;3:192197.

14. Plaschke PP, Janson C, Norrman E, et al. Onset and remission of allergic rhinitis and asthma and the relationship with atopic sensitization and smoking. Am J Respir Crit Care Med. 2000;162:920-924.

15. Chen Y, Dales R, Tang M, et al. Sex-related interactive effect of smoking and household pets on asthm incidence. Eur Respir J. 2002;20:1162-1166.

16. Piipari R, Jaakkola JJK, Jaakkola N, et al. Smoking and asthma in adults. Eur Respir J. 2004;24:734 739

17. Polosa R, Knoke JD, Russo C, et al. Cigarette smoking is associated with a greater risk of inciden asthma in allergic rhinitis. J Allergy Clin Immunol. 2008;121:1428-1434.

18. Strachan D, Cook D. Parental smoking and child hood asthma: longitudinal and case-control studies. Thorax. 1998;53:204-212.

19. U.S. Department of Health and Human Services. The Health Consequences of Involuntary Exposure to Tobacco Smoke: A Report of the Surgeon General. Atlanta: Centers for Disease Control and PrevenAtlanta: Centers for Disease Control and Preven-
tion, National Center for Chronic Disease Prevention, Nation; 2006.

20. Burke H, Leonardi-Bee J, Hashim A, et al. Prenatal and passive smoke exposure and incidence of asthma and wheeze: systematic review and meta-analysis. $P e-$ diatrics. 2012;129:735-744.

21. Accordini S, Janson C, Svanes C, et al. The role of smoking in allergy and asthma: lessons from the ECRHS. Curr Allergy Asthma Rep. 2012;12:185191.
22. Skorge T, Eagan T, Eide G, et al. The adult incidence of asthma and respiratory symptoms by passive smoking in utero or in childhood. Am J Respir Crit Care Med. 2005;172:61-66.

23. Centers for Disease Control and Prevention. National Center for Health Statistics. FastStats. Health Status and Risk Factors. Alcohol and Drug Use. Smoking. April 8, 2015. http://www.cdc.gov/ Use. Smoking. April 8, 2015. http://www.cdc.gov/
nchs/fastats/smoking.htm. Accessed May 14, 2015.

24. Spears M, Cameron E, Chaudhuri R, et al. Challenges of treating asthma in people who smoke. Expert Rev Clin Immunol. 2010;6:257-268.

25. Chalmers GW, Macleod KJ, Little SA, et al. Influence of cigarette smoking on inhaled corticosteroid treatment in mild asthma. Thorax. 2002;57:226-230.

26. Lazarus SC, Chinchilli VM, Rollings NJ, et al. Smoking affects response to inhaled corticosteroids or leukotriene receptor antagonists in asthma. Am J Respir Crit Care Med. 2007;175:783-790.

27. Tomlinson JE, McMahon AD, Chaudhuri R, et al. Efficacy of low and high dose inhaled corticosteroid in smokers versus nonsmokers with mild asthma. Thorax. 2005;60:282-287.

28. Jung KH, Hsu S-I, Moors KM, et al. Childhood exposure to fine particulate matter and black carbon and the development of new wheeze between ages 5 and 7 in an urban prospective cohort. Environ Int. 2012;45:44-50.

29. Togias A, Fenton MJ, Gergen PJ, Rotrosen D, Fauci AS. Asthma in the inner city: the perspective of the National Institute of Allergy and Infectious Diseases. J Allergy Clin Immunol. 2010;125:540-544.

30. Matsui EC. Environmental exposures and asthma morbidity in children living in urban neighbourhoods. Allergy. 2013:69:553-558.

31. Morgan WJ, Crain EF, Gruchalla RS, et al. Results of a home-based environmental intervention among urban children with asthma. N Engl J Med. 2004;351:1068-1080

32. Eggleston PA, Butz A, Rand C, et al. Home environmental intervention in innercity asthma: a 
randomized controlled clinical trial. Ann Allergy Asthma Immunol. 2005;95:518-524.

33. Keet CA, McCormack MC, Peng RD, Matsui EC. Age- and atopy-dependent effects of vitamin D on wheeze and asthma. J Allergy Clin Immunol. 2011;128:414-416.

34. Matsui EC, Matsui W. Higher serum folate levels are associated with a lower risk of atopy and wheeze. $J$ Allergy Clin Immunol. 2009;123:1253-1259.

35. Wu AC, Tantisira K, Li L, Fuhlbrigge AL, Weiss ST, Litonjua A. Effect of Vitamin D and inhaled corticosteroid treatment on lung function in children. $\mathrm{Am}$ J Respir Crit Care Med. 2012;186:508-513.

36. Simons E, Curtin-Brosnan J, Buckley T, Breysse $\mathrm{P}$, Eggleston PA. Indoor environmental differences between inner city and suburban homes of children with asthma. J Urban Health. 2007;84:577590.

37. McCormack MC, Breysse PN, Matsui EC, et al. Inhome particle concentrations and childhood asthma morbidity. Environ Health Perspect. 2009;117:294298.

38. Sousa SI, Ferraz C, Alvim-Ferraz MC, Vaz LG, Marques AJ, Martins FG. Indoor air pollution on nurseries and primary schools: impact on childhood asthma-study protocol. BMC Public Health. 2012;12:435

39. Annesi-Maesano I, Hulin M, Lavaud F, et al. Poor air quality in classrooms related to asthma and rhinitis in primary schoolchildren of the French 6 Cities Study. Thorax. 2012;67:682-688.

40. Hulin M, Caillaud D, Annesi-Maesano I. Indoor air pollution and childhood asthma: variations between urban and rural areas. Indoor Air. 2010;20:502514.

41. Miller RL, Peden DB. Environmental effects on immune responses in patients with atopy and asthma. $J$ Allergy Clin Immunol. 2014:134:1001-1008.

42. Lu KD, Breysse PN, Diette GB, et al. Being overweight increases susceptibility to indoor pollutants among urban children with asthma. I Allergy Clin Immunol. 2013;131:1017-1023.

43. Weiss ST. Obesity: insight into the origins of asthma. Nat Immunol. 2005;6:537-539.

44. Sutherland ER. Linking obesity and asthma. Ann N Y Acad Sci. 2014:1311;31-41.

45. Moore WC, Meyers DA, Wenzel SE, et al. Identification of asthma phenotypes using cluster analysis in the Severe Asthma Research Program. Am J Respir Crit Care Med. 2010;181:315-323.

46. Sutherland ER, Goleva E, King TS, et al. Cluster analysis of obesity and asthma phenotypes. PLoS One. 2012;7:e36631.

47. Boulet L, Franssen E. Influence of obesity on response to fluticasone with or without salmeterol in moderate asthma. Respir Med. 2007;101:2240-2247.

48. Peters-Golden M, Swern A, Bird SS, et al. Influence of body mass index on the response to asthma controller agents. Eur Respir J. 2006;27:495-503.

49. Sutherland ER, Goleva E, Strand M, et al. Body mass and glucocorticoid response in asthma. Am J Respir Crit Care Med. 2008;178:682-687.

50. Malo JL, Vandenplas O. Definitions and classification of work-related asthma. Immunol Allergy Clin North Am. 2011;31:645-662.

51. Tan J, Bernstein JA. Occupational asthma: an overview. Curr Allergy Asthma Rep. 2014;431:1-7.

52. Karvala K, Toskala E, Luukkonen R, Uitti J, Lappalainen S, Nordman H.. Prolonged exposure to damp and moldy workplaces and new-onset asthma. Int Arch Occup Environ Health. 2011;84:713-721.

53. Fuchs O, vonMutius E. Prenatal and childhood infections: implications for the development and treatment of childhood asthma. Lancet Resp Med. 2013:1:743-754

54. Kieninger E, Fuchs O, Latzin P, Frey U, Regamey N. Rhinovirus infections in infancy and early childhood. Eur Respir J. 2013;41:443-452.

55. Xepapadaki P, Skevaki CL, Papadopoulos NG. The role of viral and bacterial infections on the development and exacerbations of asthma. In: Carlsen KH, Gerritsen J, eds. Paediatric Asthma. 2012:116128 .

56. Sly PD, Boner AL, Bjorksten B, et al. Early identification of atopy in the prediction of persistent asthma in children. Lancet. 2008;372:1100-1006.

57. Holt PG, Sly PD. Viral infections and atopy in asthma pathogenesis: new rationales for asthma prevention and treatment. Nat Med. 2012;18:726-735.

58. Holtzman MJ. Asthma as a chronic disease of the innate and adaptive immune systems responding to viruses and allergens. J Clin Invest. 2012;122:27412748 .

59. Stein RT, Sherrill D, Morgan WJ, et al. Respiratory syncytial virus in early life and risk of wheeze and allergy by age 13 years. Lancet. 1999;354:541-545.

60. James KM, Gebretsadik T, Escobar GJ, et al. Risk of childhood asthma following infant bronchiolitis during the respiratory syncytial virus season. J Allergy Clin Immunol. 2013;132:227-229.

61. Edwards MR, Bartlett NW, Hussell T, Openshaw P, Johnston SL. The microbiology of asthma. Nat Rev Microbiol. 2012;10:459-471.

62. Bufford JD, Gern JE. The hygiene hypothesis revisited. Immunol Allergy Clin North Am. 2005;25:247262

63. Chu HW, Honour JM, Rawlinson CA, Harbeck RJ, Martin RJ. Hygiene hypothesis of asthma: a murine asthma model with Mycoplasma pneumoniae infection. Chest. 2003;123(Suppl):390S

64. Prokopakis E, Vardouniotis A, Kawauchi H, et al. The pathophysiology of the hygiene hypothesis. Int J Pediatr Otolaryngol. 2013;77:1065-1077.

65. Rosenberg SL, Miller GE, Brehm JM, Celedon JC. Stress and asthma: novel insights on genetic, epigenetic, and immunologic mechanisms. I Allergy Clin Immunol. 2014;134:1009-1015.

66. Ressler KJ, Mercer KB, Bradley B, et al. Posttraumatic stress disorder is associated with PACAP and the PAC1 receptor. Nature. 2011;470:492497.

67. Duffy DL, Martin NG, Battistutta D, Hopper JL, Mathews JD. Genetics of asthma and hay fever in Australian twins. Am Rev Respir Dis. 1990;142(6 Pt 1):1351-1358

68. Harris JR, Magnus P, Samuelsen SO, Tambs K. No evidence for effects of family environment on asthma. A retrospective study of Norwegian twins. Am J Respir Crit Care Med. 1997;156:43-49.

69. Koppelman GH, Los H, Postma DS. Genetic and environment in asthma: the answer of twin studies. Eur Respir J. 1999;13:2-4.

70. Nieminen MM, Kaprio J, Koskenvuo M. A population-based study of bronchial asthma in adult twin pairs. Chest. 1991;100:70-75.

71. Deichmann KA, Starke B, Schlenther S, et al. Linkage and association studies of atopy and the chromosom $11 \mathrm{q} 13$ region. J Med Genet. 1999;36:379-382.

72. Ober C, Hoffjan S. Asthma genetics 2006: the long and winding road to gene discovery. Genes Immun. 2006;7:95-100.

73. Vercelli D. Discovering susceptibility genes for asthma and allergy. Nat Rev Immunol. 2008;8:169182.

74. Zhang J, Pare PD, Sandford AJ. Recent advances in asthma genetics. Respir Res. 2008;9:4.

75. Liggett SB. Genetics of beta 2-adrenergic receptor variants in asthma. Clin Exp Allergy. 1995;25(Suppl 2):89-94; discussion 95-96.

76. Martinez FD, Graves PE, Baldini M, Solomon S, Erickson R. Association between genetic polymorphisms of the beta2-adrenoceptor and response to albuterol in children with and without a history of wheezing. J Clin Invest. 1997;100:31843188 .

77. Potter PC, VanWyk L, Martin M, Lentes KU, Dowdle EB. Genetic polymorphism of the beta- 2 adrenergic receptor in atopic and non-atopic subjects. Clin Exp Allergy. 1993;23:874-877.

78. Basehore MJ, Howard TD, Lange LA, et al. A comprehensive evaluation of IL4 variants in ethnically diverse populations: association of total serum $\operatorname{IgE}$ levels and asthma in white subjects. J Allergy Clin Immunol. 2004;114:80-87.

79. Haller G, Torgerson DG, Ober C, Thompson EE. Sequencing the IL4 locus in African Americans implicates rare noncoding variants in asthma susceptibility. I Allergy Clin Immunol. 2009;124:12041209.e9.

80. Munthe-Kaas MC, Carlsen KH, Haland G, et al. T cell-specific T-box transcription factor haplotype is associated with allergic asthma in children. J Allergy Clin Immunol. 2008; 121:51-56.

81. Pykalainen M, Kinos R, Valkonen S, et al. Association analysis of common variants of STAT6, GATA3, and STAT4 to asthma and high serum IgE phenotypes. J Allergy Clin Immunol. 2005;115:80-87.

82. Randolph AG, Lange C, Silverman EK, et al. The IL12B gene is associated with asthma. Am J Hum Genet. 2004;75:709-715.

83. Suttner K, Rosenstiel P, Depner M, et al. TBX21 gene variants increase childhood asthma risk in combina- tion with HLX1 variants. I Allergy Clin Immunol. 2009;123:1062-1068.e8.

84. Tantisira KG, Hwang ES, Raby BA, et al. TBX21: a functional variant predicts improvement in asthma with the use of inhaled corticosteroids. Proc Natl Acad Sci U S A. 2004;101:18099-18104.

85. Zhou H, Hong X, Jiang S, Dong H, Xu X. Analyses of associations between three positionally cloned asthma candidate genes and asthma or asthmarelated phenotypes in a Chinese population. BMC Med Genet. 2009;10:123.

86. Howard TD, Koppelman GH, Xu J, et al. Genegene interaction in asthma: IL4RA and IL13 in a Dutch population with asthma. Am J Hum Genet. 2002;70:230-236.

87. Kabesch M, Schedel M, Carr D, et al. IL-4/IL-13 pathway genetics strongly influence serum IgE levels and childhood asthma. J Allergy Clin Immunol. 2006;117:269-274.

88. Potaczek DP, Nishiyama C, Sanak M, Szczeklik A, Okumura K. Genetic variability of the highaffinity $\operatorname{IgE}$ receptor $\alpha$-subunit $(\mathrm{Fc} \varepsilon \mathrm{RI} \alpha)$. Immunol Res. 2009;45:75-84.

89. Vladich FD, Brazille SM, Stern D, Peck ML, Ghittoni R, Vercelli D. IL-13 R130Q, a common variant associated with allergy and asthma, enhances effector mechanisms essential for human allergic inflammation. J Clin Invest. 2005;115:747-754.

90. Wu X, Li Y, Chen Q, et al. Association and gene-gene interactions of eight common single-nucleotide polymorphisms with pediatric asthma in middle china. $J$ Asthma. 2010;47:238-244.

91. Altshuler D, Daly MJ, Lander ES. Genetic mapping in human disease. Science. 2008;322:881-888.

92. McCarthy MI, Abecasis GR, Cardon LR, et al. Genome-wide association studies for complex traits: consensus, uncertainty and challenges. Nat Rev Genet. 2008;9:356-369.

93. Weiss ST, Raby BA, Rogers A. Asthma genetics and genomics 2009. Curr Opin Genet Dev. 2009;19:279-282.

94. Holloway JW, Yang IA, Holgate ST. Genetics of allergic disease. J Allergy Clin Immunol. 2010;125(Suppl 2):S81-S94.

95. Rakyan VK, Down TA, Balding DJ, Beck S. Epigenome-wide association studies for common human diseases. Nat Rev Genet. 2011;12:529-541.

96. Relton CL, Davey Smith G. Two-step epigenetic Mendelian randomization: a strategy for establishing the causal role of epigenetic processes in pathways to disease. Int J Epidemiol. 2012;41:161-176.

97. Begin P, Nadeau KC. Epigenetic regulation of asthma and allergic disease. Allergy Asthma Clin Immunol. 2014:10;1-12.

98. Palmer LJ, Burton PR, Faux JA, James AL, Musk $\mathrm{AW}$, Cookson WO. Independent inheritance of serum immunoglobulin $\mathrm{E}$ concentrations and airway responsiveness. Am J Respir Crit Care Med. 2000;161:1836-1843.

99. Cookson W, Moffatt M, Strachan DP: Genetic risks and childhood-onset asthma. I Allergy Clin Immunol. 2011;128:266-270.

100. Moffatt MF, Gut IG, Demenais F, et al.; GABRIEL Consortium. A large-scale, consortiumbased genomewide association study of asthma. $N$ Engl J Med. 2010;363:1211-1221.

101. Passerini L, Santoni de Sio FR, Roncarolo MG, Bacchetta R. Forkhead box P3: the peacekeeper of the immune system. Int Rev Immunol. 2014;33:129145.

102. Zheng Y, Josefowicz S, Chaudhry A, Peng XP, Forbush K, Rudensky AY. Role of conserved non-coding DNA elements in the Foxp3 gene in regulatory T-cell fate. Nature. 2010;463:808-812.

103. Kim HP, Leonard WJ. CREB/ATF-dependent T cell receptor-induced FoxP3 gene expression: a role for DNA methylation. J Exp Med. 2007;204:15431551.

104. Polansky JK, Kretschmer K, Freyer J, et al. DNA methylation controls Foxp3 gene expression. Eur J Immunol. 2008;38:1654-1663.

105. Haiqi H, Yong Z, Yi L. Transcriptional regulation of Foxp3 in regulatory T cells. Immunobiology. 2011;216:678-685.

106. Ohkura N, Kitagawa Y, Sakaguchi S. Development and maintenance of regulatory $\mathrm{T}$ cells. Immunity. 2013;38:414-423.

107. Zhang Y, Maksimovic J, Naselli G, et al. Genomewide DNA methylation analysis identifies hypomethylated genes regulated by FOXP3 in human regulatory T cells. Blood. 2013;122:2823-2836. 